Hall, R. P. \& Friend, C. R. L. 1979: Structural evolution of the Archaean rocks in Ivisârtoq and the neighbouring inner Godthåbsfjord region, southern West Greenland. Geology 7, 311-315.

McGregor, V. R. 1973: The early Precambrian gneisses of the Godthåb district, West Greenland. Phil. Trans. R. Soc. Lond. A 273, 343-358.

McGregor, V. R. 1979: Archaean gray gneisses and the origin of the continental crust: evidence from the Godthåb region, West Greenland. In Barker, F. (edit.) Trondhjemites, dacites and related rocks, 169-204. Amsterdam: Elsevier.

Moorbath, S. 1976: Age and isotope constraints for the evolution of Archaean crust. In Windley, B. F. (edit.) The early history of the earth, 351-360. London: Wiley.

Moorbath, S. 1977: Ages, isotopes and evolution of Precambrian continental crust. Chem. Geol. 20, 151-187.

Pearce, J. A. 1976: Statistical analysis of major element patterns in basalts. J. Petrol. 17, $15-43$.

Department of Geology, Portsmouth Polytechnic, Portsmouth POI $3 Q L$,

U.K.

\title{
Investigations on amphibolite facies orthogneisses, amphibolites and leucogabbros on Akugdlerssuaq, inner Godthåbsfjord
}

\section{A. P. Nutman}

Two weeks of June 1981 were spent examining the amphibolite facies orthogneisses, amphibolites and leucogabbros of Akugdlerssuaq, inner Godthåbsfjord (fig. 24). This area was visited by V. R. McGregor during the helicopter reconnaissance mapping programme of Godthåbsfjord in 1976 (Allaart et al., 1977). McGregor observed a sharp, concordant contact between a layered complex of amphibolite, leucogabbro and anorthosite and a unit of banded gneisses, considered to be predominantly Amîtsoq. The area was revisited in 1981 for more detailed study of the relation between the orthogneisses and layered complex. Equal emphasis was placed on mapping at a scale of approximately 1:20000, detailed study of selected outcrops and sampling for geochemical and isotopic studies.

\section{Geological divisions}

The area can be divided into five zones, zone $I$ being the lowest and zone $V$ the highest (fig. 24). Zones I to III were examined in more detail than IV and V.

Zone I comprises multiphase pegmatite banded biotite-hornblende tonalitic-granodioritic gneisses. Subconcordant intrusive sheets of schlieric pegmatitic gneiss and of grey gneiss occur locally. More massive grey tonalitic gneiss units within the banded gneisses may be a distinct phase. Pods of amphibolite, ultramafic rocks and quartz-rich rocks within the banded gneisses form less than 5 per cent of the zone. Most of the amphibolite is fine grained 


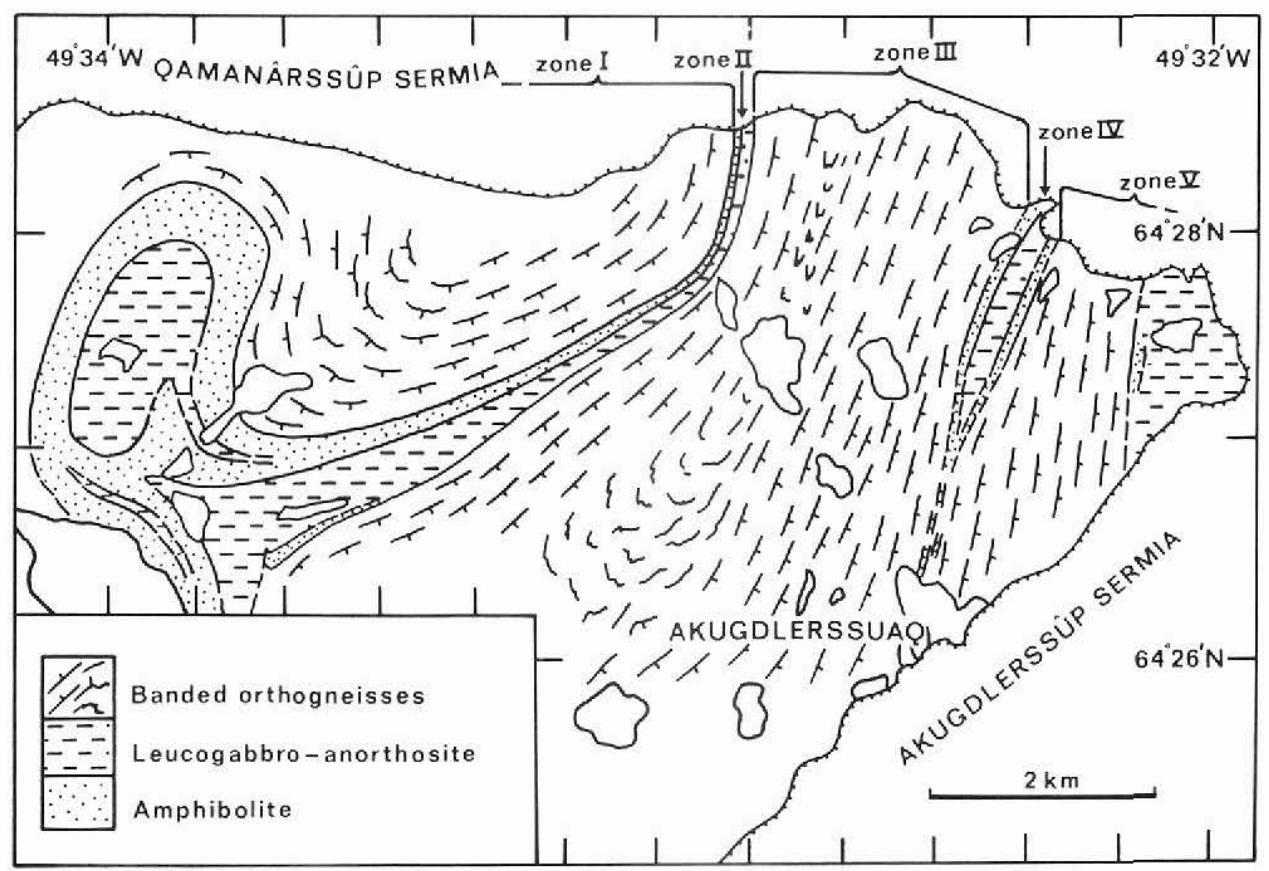

Fig. 24. Geological divisions of Akugdlerssuaq, inner Godthåbsfjord.

and homogeneous, and occurs as pods, commonly net veined by pegmatitic neosome, that are usually less than $1 \mathrm{~m}$ thick. These pods occur as trains that can be traced over the length of individual outcrops and are concordant to the compositional banding of the gneisses. They are interpreted as Ameralik dykes that have been broken up tectonically and modified by emplacement of pegmatites. The quartz-rich gneiss pods comprise banded quartz-magnetite and quartz-clinopyroxene-amphibole rocks, similar to lithologies found in the Akilia association (McGregor \& Mason, 1977).

Zone I is interpreted as containing an Amîtsoq gneiss component, probably a large one, which has been severely (tectonometamorphically) modified under amphibolite facies conditions after intrusion of Ameralik dykes. The sheets of younger gneiss in the zone could be contemporaneous with the Nûk gneiss or the intrusion of the granitic dykes at Qârusuk.

Zone II comprises a lower amphibolite unit overlain by an upper leucogabbro-anorthosite unit. A thin, lenticular unit of amphibolite (lithologically similar to the lower amphibolite unit) overlies the leucogabbros-anorthosites in the western part of the investigated area. The lower parts of the amphibolite unit are mesocratic and homogeneous to weakly layered. The upper parts of the amphibolite unit are more banded (on a 10 to $100 \mathrm{~cm}$ scale) and are more melanocratic. Ultramafic rocks and clinopyroxene-rich amphibolites occur towards the upper margin. The upper part also contains lenses and smears of garnet-biotite gneiss locally. The amphibolites have hornblende-plagioclase-clinopyroxene-garnet assemblages, and local coarse grained metamorphic segregations/incipient partial melt sweats. Garnet does not contain cores of pyroxene or amphibole and appears to coexist stably with other phases. 
Where best preserved, the ultramafic rocks contain relict clinopyroxene, but more commonly they occur as amphibole schists. The layering of the amphibolites and the ultramafic rocks is interpreted as a tectonically modified igneous feature. No structures are preserved to show the way-up of the unit.

In most sections across zone II the leucogabbro-anorthosite unit overlies the lower amphibolite unit concordantly, with a transition zone up to $5 \mathrm{~m}$ thick between them of concordantly interlayered lithologies common to both of the units. However, in the north-west, where deformation is less intense, concordant sheets of anorthosite occur in the upper part of the amphibolite unit, and the lower part of the leucogabbro-anorthosite unit locally contains diffuse-margined smears and pods of amphibolite and garnetiferous rocks. These features suggest that the leucogabbro-anorthosite was intruded into and locally reacted with the amphibolite unit.

The leucogabbro-anorthosite unit now has a maximum thickness of $100 \mathrm{~m}$. Some horizons are intensely deformed, with shearing concordant to the compositional banding. Thus the sequence of lithologies present may not be the original igneous stratigraphy. Where the leucogabbro-anorthosite unit is free of inclusions, its lower part is composed of fine grained anorthosite with a few thin bands of leucogabbro. This is overlain by leucogabbro-anorthosites with 'tennis ball' structures (plagioclase megacrysts in a finer-grained, hornblendeplagioclase matrix). The uppermost part (observed only locally) consists of fine-grained anorthosites and leucogabbros interlayered on a 10 to $100 \mathrm{~cm}$ scale. Hornblende is the commonest mafic species in the leucogabbros and anorthosites, while garnet and clinopyroxene occur locally. Neither orthopyroxene nor high concentrations of magnetite or chromite were observed in the field.

The leucogabbro-anorthosite unit locally contains concordant layers of amphibolite, seen in areas of less deformation to be irregularly-margined dykes. These have not been observed in the amphibolite unit. In the east zone II is intruded by pegmatitic to tonalitic gneisses. These are discussed in the section on contact relations.

Zone III comprises banded gneisses with general characteristics the same as zone I. Locally the discontinuous layers of homogeneous amphibolite are better preserved. Individual amphibolites are up to $50 \mathrm{~m}$ long and have parallel margins. Like the most distinctive Ameralik dyke lithology, some of these amphibolite layers contain plagioclase aggregates. There are also pods of banded amphibolites and ultramafic rocks (commonly extensively veined by pegmatite), but none of the quartz-rich gneisses that are characteristic of the Akilia association have been found. However, the similarity of these gneisses with those of zone I, and the occurrence of Ameralik-dyke-type amphibolite layers suggests that zone III, like zone $I$, is comprised predominantly of Amitsoq gneisses.

Zone IV has margins of homogeneous to poorly banded amphibolite and a core of leucogabbro and anorthosite. These have the same parageneses as equivalent lithologies of zone II. Zone IV is poorly exposed, and tapers southwards, being represented at the northern edge of Akugdlerssûp sermia by intensely banded interlayered amphibolites, garnetiferous gneisses and tonalitic gneisses. The western margin of zone IV is veined concordantly by deformed pegmatite and the eastern margin is veined by tonalitic gneisses. The marginal amphibolites are similar to those of zone II, except that no ultramafic layers have been found. The outer part of the leucogabbro-anorthosite unit comprises fine-grained, weakly banded to homogeneous anorthosite and leucogabbro, locally so highly deformed that it has been modified into an intensely lineated schist. There are locally amphibolitic and gar- 
net-rich schlieren, which may be highly deformed and altered enclaves of the marginal amphibolites. 'Tennis ball' structures occur widely in the central part of the leucogabbroanorthosite. They are now generally highly deformed, and occur as rods parallel to the regional mineral lineation.

Zone $V$ is heterogeneous. Near its contact with zone IV there are pegmatite-banded grey gneisses with trains of homogeneous amphibolite pods and also a horizon of lenticles of Akilia-association-type banded quartz-clinopyroxene-amphibole rock. These gneisses are considered to be Amitsoq. Eastwards they are overwhelmed by concordant sheets of more homogeneous tonalitic-granodioritic gneisses, interpreted as equivalent to Nûk gneisses. In the far east such gneisses sheet, and locally break up, a leucogabbro-anorthosite body with associated peripheral amphibolite.

\section{Contact relations}

The nature of the contact between zones I and II is variable. In the west it is marked by a layer of sheared rocks less than $50 \mathrm{~cm}$ wide containing deformed pegmatite veins. The contact orthogneisses of zone I are well layered, and within $3 \mathrm{~m}$ of the contact they contain parallel-margined homogeneous amphibolite layers up to $20 \mathrm{~cm}$ thick, which locally have sheared margins or are disrupted by sheets of younger homogeneous pale gneiss. These amphibolites may correlate with those of zone II. Unlike the trains of amphibolite pods interpreted as derived from Ameralik dykes, they are not extensively broken up by pegmatite. In this part of the area zone II is cut locally by irregular, subconcordant sheets of pegmatitic gneisses and highly discordant, weakly deformed, aplitic dykes.

To the east, the boundary between zones I and II is marked by schlieric pegmatite gneisses and zone II is intruded by grey gneiss and pegmatite. The pegmatitic boundary unit is up to $100 \mathrm{~m}$ wide and is intensely deformed with dislocation planes and flaser textures. Near the contact with zone $I$ it contains schlieren of banded grey gneiss with rare pods of Akilia-association-type quartz-rich rocks; these never occur together with the homogeneous amphibolite rafts that are found towards the contact with zone II. The homogeneous amphibolites of zone II are broken up by grey gneisses gradational into pegmatite with a strong flaser texture which grade westwards into the pegmatitic gneisses of the contact. Similar flaser gneiss also occurs within zone $I$ as sheets less than $1 \mathrm{~m}$ thick that occupy shear zones discordant to the compositional banding of their host. When followed into the contact between zones I and II these sheets turn abruptly into concordance with the banding of the country rocks, and can no longer be distinguished as a separate phase. Rather poorly banded grey gneisses streaked and veined by penecontemperaneous pegmatite locally invade the leucogabbro-anorthosite unit as syntectonic sheets, and boudinolith structures (as defined by Stainforth, 1977) are locally developed. As a working assumption the gneiss phases intruding the leucogabbro-anorthosite and the amphibolite units are taken to be the same age.

It is possible that some of the pegmatitic gneisses along the margin of zone II in the east represent mobilisation of the gneisses due to the intrusion in situ of the magmatic parents of the leucogabbros, anorthosites and amphibolites. Field evidence suggests that the leucogabbro-anorthosite and the amphibolite units are separate phases. Thus if either of them were emplaced as magmas, the thermal effect on the country rocks at any given time would be less severe than if the leucogabbros, anorthosites and amphibolites were emplaced as a single body. This interpretation of the relations may account for the lack of more widespread 
mobilisation of the contact gneisses. The amphibolite sheets in the gneisses close to the western part of the boundary are provisionally correlated with the amphibolite unit of zone II, and may have been intrusive sheets rotated into concordance with the banding of their host during subsequent deformation.

No unequivocal evidence of the original nature of the boundary between zones I and II was found. The boundary is provisionally interpreted as an intrusive contact that was later modified tectonically, and obscured locally by intrusive gneiss sheets.

The contact between zones II and III is marked by flaggy, sheared gneisses with horizons of blastomylonite and some subconcordant pegmatite veining. The gneisses of zone III near to the contact are strongly banded. This contact is interpreted as a major dislocation, probably a thrust.

The contact between zones III and IV is rather similar to that between zones I and II, except that the tract of pegmatite sheeting along the contact is broader. The marginal amphibolites of zone IV and the Amitsoq gneiss component of zone V are intruded by concordant sheets of pegmatite-streaked, rather homogeneous grey gneiss. The actual contact is not exposed. It is not known if the zone IV leucogabbros, anorthosites and amphibolites were intruded into, or tectonically juxtaposed with, the Amîtsoq component of zone V.

It is concluded that the contacts between some of the zones are tectonic (probably thrusts). It is uncertain whether the others formed as trusts or if they are the modified contacts of composite leucogabbro-anorthosite-gabbro intrusion into Amîtsoq gneisses.

\section{Structure}

The contacts interpreted as thrusts formed early in the structural history, and are provisionally correlated with those of the Godthåb district (D2 of Chadwick \& Nutman, 1979). Compositional banding and the regional foliation are generally concordant, but locally there are tight to isoclinal folds in trains of amphibolite pods and the compositional banding of the gneisses to which the foliation is axial planar. In the centre of zone III there is a tract of such small folds. The sense of these folds is rather confused and their limbs are locally sheared-out parallel to the foliation. Possibly they lie in the axial zone of a large D3 fold (terminology of Chadwick \& Nutman, 1979). If so, zones II and IV could be equivalent.

The main lithological units outline large asymmetric structures with axes trending west of south (fig. 24). These structures are the same style as (and are correlated with) D4 structures of the north-western Buksefjorden region (Chadwick \& Nutman, 1979) and late, upright asymmetric structures in Godthåbsfjord (V.R. McGregor, personal communication, 1981).

Acknowledgements. I thank V. R. McGregor for discussions of the geology of the area, for loaning me his field data and for criticism of this paper. Thanks also to the team at the Qamanârssup sermia glaciological station for logistical support and letting me share their accommodation.

\section{References}

Allaart, J. H., Jensen, S. B., McGregor, V. R. \& Walton, B. J. 1977: Reconnaissance mapping for the 1:500 000 map sheet in the Godthåb-Isua region, southern West Greenland. Rapp. Grønlands geol. Unders. 85, 50-54. 
Chadwick, B. \& Nutman, A. P. 1979: Archaean structural evolution in the northwest of the Buksefjorden region, southern West Greenland. Precambrian Res. 9, 199-226.

McGregor, V. R. \& Mason, B. 1977: Petrogenesis and geochemistry of metabasaltic and metasedimentary enclaves in the Amîtsoq gneisses West Greenland. Amer. Miner. 62, 887-904.

Stainforth, J. G. 1977: The structural geology of the area between Ameralik and Buksefjorden, southern West Greenland. Unpubl. thesis, Univ. Exeter.

\title{
Reconnaissance mapping of the Precambrian rocks between Uîvaq $\left(63^{\circ} 03^{\prime} \mathrm{N}\right)$ and Bernstorffs Isfjord $\left(63^{\circ} 38^{\prime} \mathrm{N}\right)$, South-East Greenland
}

\author{
Jan C. Escher and Troels F. D. Nielsen
}

A programme for the mapping of the Archaean and Nagssugtoqidian rocks between $62^{\circ} 30^{\prime}$ and $67^{\circ} 00^{\prime}$ on the south-east coast of Greenland was initiated in August 1981(fig. 25). The aim of the programme is the production of a 1:500 000 geological map sheet (sheet no. 14) covering the Tingmiarmiut-Angmagssalik region. Due to the late retreat of the pack ice in South-West and South-East Greenland in 1981, the field season was limited to 17 working days. Logistic support for the two mapping parties was provided by two inflatable dingies with outboard motors and by the GGU motor cutter $K . J . V$. Steenstrup. This summer's investigations only covered the areas accessible from the fjords, but at a later stage of the programme it is planned to visit the more remote inland areas by helicopter.

There has been little previous geological investigation of the region. R. Bøgvad sailed along the coast in 1932 during the seventh Thule expedition and reconnaissance mapping for the 1:2500000 tectonic geological map of Greenland (Escher, 1970) was carried out by D. Bridgwater and K. Gormsen during the summers of 1967 and 1968 (Bridgwater \& Gormsen, 1968, 1969). Bridgwater kindly placed all available data collected during these two expeditions at our disposal.

Although no radiometric measurements have yet been made on the rocks collected, there is little doubt that most of the rocks are of Archaean age, because of their very close resemblance to the Archaean of West Greenland.

No mineralisation of possible economic value was observed.

\section{Metamorphism and deformation}

Field evidence shows that the rocks north-east of Kangerdlikajik are of amphibolite facies, and those to the south-east are of granulite facies. The metamorphic boundary is gradual and has a NW-SE trend. The agmatitic gneisses of the amphibolite facies terrain are grey, biotite and hornblende-bearing, and contain many well-preserved inclusions. The same 